\title{
Publisher Correction: Exploring the effect of network topology, mRNA and protein dynamics on gene regulatory network stability
}

\author{
Yipei Guo (iD) \& Ariel Amir (D)
}

Correction to: Nature Communications https://doi.org/10.1038/s41467-020-20472-x, published online 8 January 2021.

The original version of this Article contained errors in Equations 17 and 18 . Both equations incorrectly read: $M_{1}=\left(T_{1} 0 R_{1} 0\right)$ and $M_{2}=$ $\left(\mathrm{T}_{2} 0 \mathrm{R}_{2} 0\right)$, respectively. The correct form of Equations 17 and 18 are: $M_{1}=\left(\begin{array}{ll}T_{1} & 0 \\ R_{1} & 0\end{array}\right)$ and $M_{2}=\left(\begin{array}{ll}T_{2} & 0 \\ R_{2} & 0\end{array}\right)$, respectively. The original version of this Article also contained an error in the fifth paragraph of the Results subsection. The Model, immediately prior to equation 8 , which incorrectly read 'numbers ${ }_{p i}$ for $i=1, \ldots, N$.' The correct version should read 'numbers $p_{i}$ for $i=1$, ..., $N$ '. Furthermore, an error occurred in the seventh paragraph of the Results subsection The Model, immediately prior to equation 9 , which incorrectly read ' $V=\sum_{i p i}$ '. The correct version should read ' $V=\sum_{i} p_{i}$ '. These have been corrected in both the PDF and HTML versions of the Article.

Published online: 08 February 2021

(i) Open Access This article is licensed under a Creative Commons Attribution 4.0 International License, which permits use, sharing, adaptation, distribution and reproduction in any medium or format, as long as you give appropriate credit to the original author(s) and the source, provide a link to the Creative Commons license, and indicate if changes were made. The images or other third party material in this article are included in the article's Creative Commons license, unless indicated otherwise in a credit line to the material. If material is not included in the article's Creative Commons license and your intended use is not permitted by statutory regulation or exceeds the permitted use, you will need to obtain permission directly from the copyright holder. To view a copy of this license, visit http://creativecommons.org/licenses/by/4.0/.

(C) The Author(s) 2021 